\title{
Is Histopathologic Subtype of Lung Cancer Changing over Time?
}

\author{
Sevket OZKAYA ${ }^{1}$, Serhat FINDIK ${ }^{2}$, Atilla G. ATICI ${ }^{2}$, Bedri KANDEMIR ${ }^{3}$, Levent ERKAN ${ }^{2}$ \\ ${ }^{1}$ Rize University, Faculty of Medicine, Department of Pulmonary Medicine, Rize \\ ${ }^{2}$ Ondokuz Mayis University, Faculty of Medicine, Department of Pulmonary Medicine, Samsun \\ ${ }^{3}$ Ondokuz Mayis University, Faculty of Medicine, Department of Pathology, Atakum, Samsun, TURKEY
}

\begin{abstract}
Lung cancer is the leading cause among cancer deaths in the world. Over the recent years, there have been changes in the distribution of the histopathological subtypes of lung cancer. This study was conducted to investigate the changes in the cell-type distribution in lung cancer with regard to age, gender, and smoking history, based on a retrospective analysis of 1195 (94\% male, 6\% female) proven cases of lung cancer during the period between January 1998 and December 2007. The histopathological subtypes, ages, genders, and detailed smoking histories were obtained from the clinical files. The diagnosis in each patient was confirmed by histopathological samples from the original cancer site in the lung. The patients were divided into two groups: Group I comprised the patients who were diagnosed in the first five years (from January 1998 to December 2002) and Group II comprised the remaining patients (from January 2003 to December 2007). Squamous cell carcinoma (59.1\%) was the most common type, followed by small cell carcinoma (21.2\%) and adenocarcinoma (13.6\%). Over the study period, the incidence of squamous cell carcinoma decreased from $60.1 \%$ to $57.8 \%$ (a change of $-4 \%$, p> 0.05 ), that of small cell carcinoma decreased from $22.3 \%$ to $19.8 \%$ (a change of $-11 \%, p<0.05$ ), and the incidence of adenocarcinoma increased from $11.8 \%$ to $15.9 \%$ (a change of $+30 \%, p<0.05$ ).

Although squamous cell carcinoma is still the most common type of lung cancer, there has been a significant increase in adenocarcinoma over time that would seem to be due to changes in the characteristics of cigarettes.
\end{abstract}

Keywords: Lung cancer, Histopathology, Adenocarcinoma, Squamous cell lung carcinoma, Small cell lung carcinoma

\section{ÖZET}

\section{Akciğer Kanserinin Histopatolojik Tipi Zamanla Değişiyor mu?}

Akciğer kanseri, tüm dünyada kansere bağlı ölümlerde ilk sırayı almaktadır. Akciğer kanserinin histopatolojik tip dağlımda, geçen ylllar boyunca değişiklik olduğu bilinmektedir. Bu çalışma Ocak 1998 ile Aralık 2007 tarihleri arasında akciğer kanseri almış 1195 hastanın (\%94 erkek, \%6 kadın) epidemiyolojik özellikleri ile birlikte, hücre tipi dağıımındaki değişiklikleri retrospektif olarak incelemeyi amaçladık. Akciğer kanseri tanısı konulan hastaların yaş, cinsiyet, sigara içme durumları ve akciğer kanseri hücre tipleri değerlendirildi. Hastalar Ocak 1998 ile Aralık 2002 tarihleri arasında 1. Grup ve Ocak 2003 ile Aralık 2007 tarihleri arasında 2. Grup olarak iki gruba ayrıld. En sık histopatolojik tip skuamoz hücreli kanser (\% 59.1) idi, küçük hücreli akciğer kanseri ikinci en sık (\%21.2) ve adenokarsinom (\%13.6) idi. İki grub incelendiğinde yıllar içinde skuamoz hücreli kanserde \%60.1'den \% 57.8'e azaldığı (\% değişim \% -4, p> 0.05) , küçük hücreli akciğer kanserinde \%22.3'den \%19.8'e azalma olduğu (\% değişim \% -11, p< 0.05), ve adenokarsinoma tipinde ise \%11.8\%'den \%15.9'e artı̧̧ (\% değişim; \% +30, p< 0.05) olduğunu saptadık.

Sonuç olarak, skuamöz hücreli kanser halen en sık akciğer kanseri tipi olmasına rağmen, adenokarsinom tipinde yıllar içinde sigara alıskanlıklarındaki değişmeye bağlı olarak anlamlı derecede artış olmaktadır.

Anahtar Kelimeler: Akciğer kanseri, Histopatoloji, Adenokarsinom, Skuamöz hücreli karsinom, Küçük hücreli karsinom 


\section{INTRODUCTION}

Lung cancer is the most common cause of cancerrelated death in both men and women worldwide. The incidence of the tumor has increased progressively during the 20th century. The incidence and mortality rates are highest in developed countries, especially in Europe and the United States, and lowest in Africa, especially in the sub-Saharan region. ${ }^{1,2}$ The incidence of lung cancer is also increasing rapidly in developing nations. Changes in cigarette characteristics, smoking behavior, mortality rates from other diseases, and the aging of the population contribute to the expected increase in the incidence and mortality rates of lung cancer in developing countries. ${ }^{3}$ The World Health Organization has estimated that by the year 2025, the lung cancer deaths worldwide will have increased several-fold, primarily in the Third World countries, mainly due to globalization of tobacco use. ${ }^{4}$

Lung cancer occurs in multiple histopathological types classified by conventional light microscopy; there are four major types, including squamous cell carcinoma, adenocarcinoma, large cell carcinoma, and small cell carcinoma. Previously, squamous cell carcinoma was the most frequent type of lung cancer in the smoking populations, and small cell carcinoma was the second most frequent. The histopathological characteristics of lung cancer in a number of developed countries have changed in the past few decades, such that the frequency of adenocarcinoma has increased and that of squamous cell carcinoma has declined. ${ }^{5}$

Due to the fact that there are no detailed data about this subject in Turkey, we aimed to determine whether the histopathological characteristics of lung cancer with regard to the demographic features had changed or not over the years in patients who had presented to our clinic, which is the reference center for the mid part of the Black Sea Region of Turkey,

\section{PATIENTS AND METHODS}

The eligibility criterion of the study was a histologically documented lung cancer case encountered in our clinic between January 1998 and December 2007. Group I comprised the patients who had been diagnosed in the first five years (from January

\begin{tabular}{|lll|}
\hline \multicolumn{2}{|l|}{ Table 1. Demographic characteristics of lung cancer patients } \\
\hline Characteristics & $\begin{array}{l}\text { Group I } \\
(\mathrm{n}=654)\end{array}$ & $\begin{array}{l}\text { Group II } \\
(\mathrm{n}=541)\end{array}$ \\
\hline Age (mean) & $61.3 \pm 9.3$ & $60.8 \pm 10.6$ \\
Male & $93.3 \%$ & $93.2 \%$ \\
Female & $6.7 \%$ & $6.8 \%$ \\
Nonsmoker & $4.8 \%$ & $6.0 \%$ \\
Former smoker & $9.4 \%$ & $10.3 \%$ \\
Current smoker & $85.8 \%$ & $83.7 \%$ \\
\hline $\begin{array}{l}\text { Group I: Patients who were diagnosed in the first five years (from 1998 } \\
\text { to 2002). } \\
\text { Group II: Patients who were diagnosed in the second five years (from } \\
\text { 2003 to 2007). }\end{array}$
\end{tabular}

1998 to December 2002) and Group II comprised patients who had been diagnosed in the second five years (from January 2003 to December 2007). The demographic features including sex, age, smoking history, and histopathological subtypes for Groups I and II were then compared. The patient data were evaluated using the SPSS 10.0. The Pearson's chisquare test was used for the data analysis. A P value of $<0.05$ was considered significant. The corresponding rates were calculated as changes of values between Group I and Group II.

\section{RESULTS}

1195 patients with a histopathological diagnosis of lung cancer were enrolled between January 1998 and December 2007. The demographic features including the smoking status of the patients have been presented in Table 1. Group I consisted of 654 patients and Group II was composed of 541 patients. There was no statistically significant difference between the two groups with regard to the demographic features.

The demographic features of the patients according to the histopathological subtypes of lung cancer have been presented in Table 2. There was no statistically significant difference between the two groups with regard to age, gender, or smoking behavior of 


\begin{tabular}{|c|c|c|c|}
\hline & $\begin{array}{l}\text { Group I } \\
(n=654)\end{array}$ & $\begin{array}{l}\text { Group II } \\
(n=541)\end{array}$ & $\begin{array}{l}\text { All patients } \\
(n=1195)\end{array}$ \\
\hline \multicolumn{4}{|l|}{ Squamous cell carcinoma } \\
\hline Number of patients & 392 (60\%) & $313(57.8 \%)$ & 705 (59.0\%) \\
\hline Age (mean) & $61.8 \pm 9.4$ & $62.3 \pm 10.0$ & $62.0 \pm 9.7$ \\
\hline Male & $96.2 \%$ & $97.1 \%$ & $96.7 \%$ \\
\hline Female & $3.8 \%$ & $2.9 \%$ & $3.3 \%$ \\
\hline Nonsmoker & $3.3 \%$ & $4.4 \%$ & $3.9 \%$ \\
\hline Former smoker & $12.4 \%$ & $13.2 \%$ & $12.8 \%$ \\
\hline Current smoker & $84.3 \%$ & $82.4 \%$ & $83.4 \%$ \\
\hline \multicolumn{4}{|l|}{ Small cell carcinoma } \\
\hline Number of patients & $146(22.3 \%)$ & 107 (19.8\%) & $253(21.2 \%)$ \\
\hline Age (mean) & $62.0 \pm 9.0$ & $59.4 \pm 11.8$ & $60.7 \pm 10.4$ \\
\hline Male & $97.9 \%$ & $95.3 \%$ & $96.6 \%$ \\
\hline Female & $2.1 \%$ & $4.7 \%$ & $3.4 \%$ \\
\hline Nonsmoker & $2.1 \%$ & $2.6 \%$ & $2.4 \%$ \\
\hline Former smoker & $6.9 \%$ & $8.1 \%$ & $7.5 \%$ \\
\hline Current smoker & $91 \%$ & $89.3 \%$ & $90.2 \%$ \\
\hline \multicolumn{4}{|l|}{ Adenocarcinoma } \\
\hline Number of patients & $80(11.8 \%)$ & $86(15.9 \%)$ & $166(13.9 \%)$ \\
\hline Age (mean) & $60.2 \pm 9.4$ & $60.6 \pm 10.1$ & $60.4 \pm 9.8$ \\
\hline Male & $85.7 \%$ & $87.2 \%$ & $86.5 \%$ \\
\hline Female & $14.3 \%$ & $12.8 \%$ & $13.6 \%$ \\
\hline Nonsmoker & $9 \%$ & $10.9 \%$ & $10 \%$ \\
\hline Former smoker & $8.9 \%$ & $9.7 \%$ & $9.3 \%$ \\
\hline Current smoker & $82.1 \%$ & $79.4 \%$ & $80.6 \%$ \\
\hline
\end{tabular}

the patients in each subtype of lung cancer. Squamous cell carcinoma (59.1\%) was the most common type, followed by small cell carcinoma (21.2\%) and adenocarcinoma (13.6\%).

Over the study period, the incidence of squamous cell carcinoma decreased from $60.1 \%$ to $57.8 \%$ (a change of $-4 \%, p>0.05$ ); that of small cell carcinoma decreased from $22.3 \%$ to $19.8 \%$ (a change of $-11 \%, \mathrm{p}<0.05)$, and that of adenocarcinoma increased from $11.8 \%$ to $15.9 \%$ (a change of $+30 \%$, p < 0.05) (Table 3).

The changes in the percentage rates of histopathological subtypes of Groups I and II have also been displayed as curves in Figures 1-4.

\section{DISCUSSION}

1195 patients were diagnosed with lung cancer in our clinic between 1998 and 2008. Among these cases, squamous cell carcinoma remained the most common type, followed by small cell carcinoma and adenocarcinoma. However, over the study period, while the percentages of squamous cell carcinoma and small cell carcinoma decreased (a change of $-4 \%$ and $-11 \%$, respectively), the percentage of adenocarcinoma increased (a change of $+30 \%$ ).

In the initial decades of the smoking-caused epidemic of lung cancer, squamous cell carcinoma was the most frequent type of lung cancer and small cell carcinoma was the second most common. In the la- 


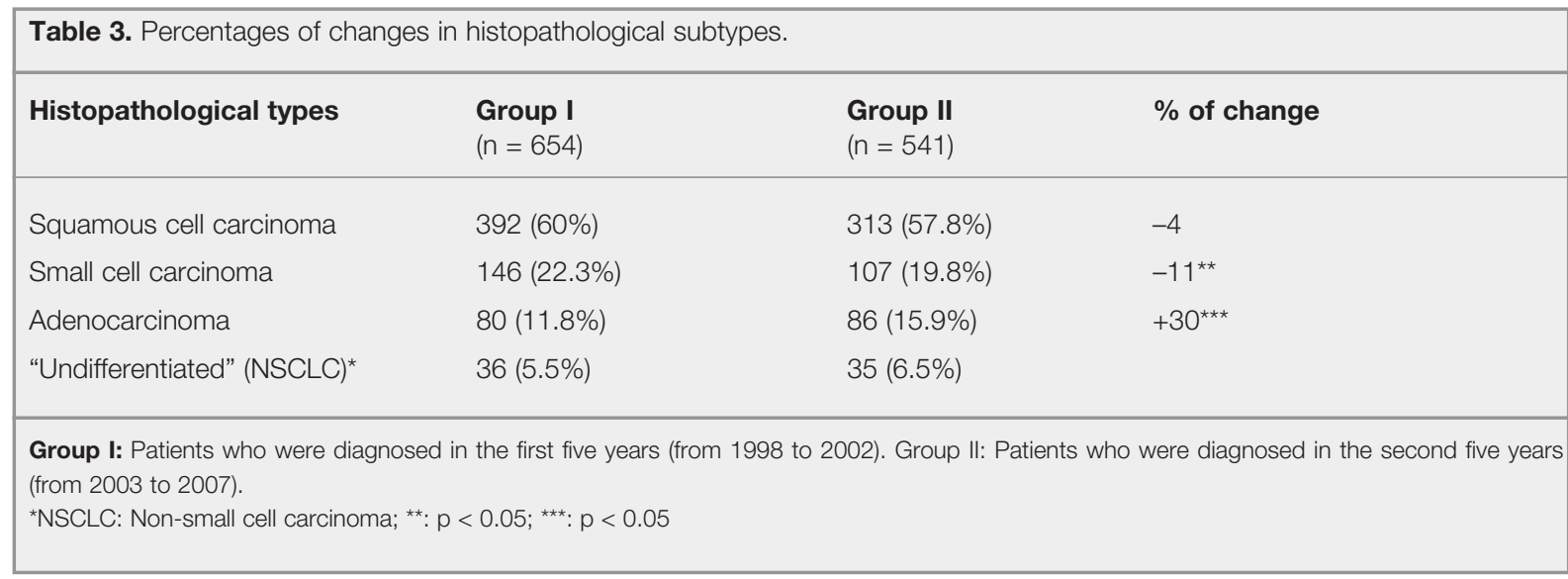

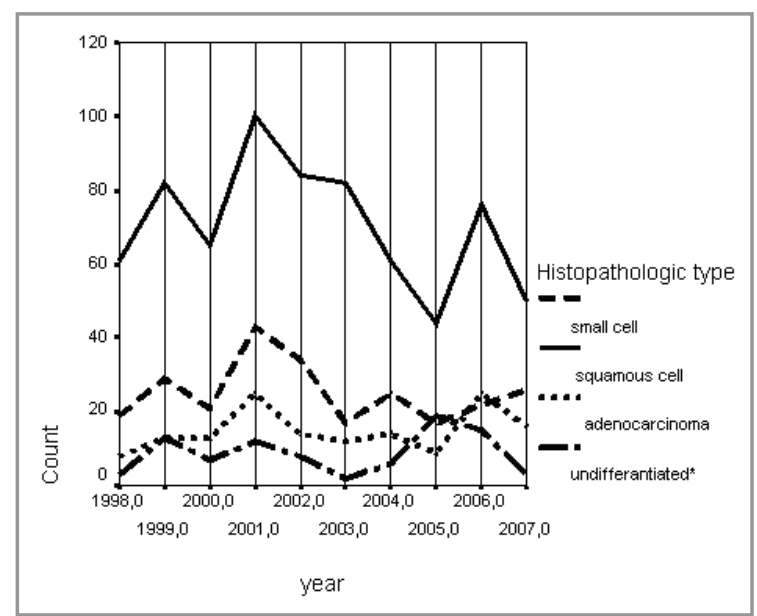

Figure 1. Graphics showing the changes in histopathological subtypes for all patients during 1998-2007.

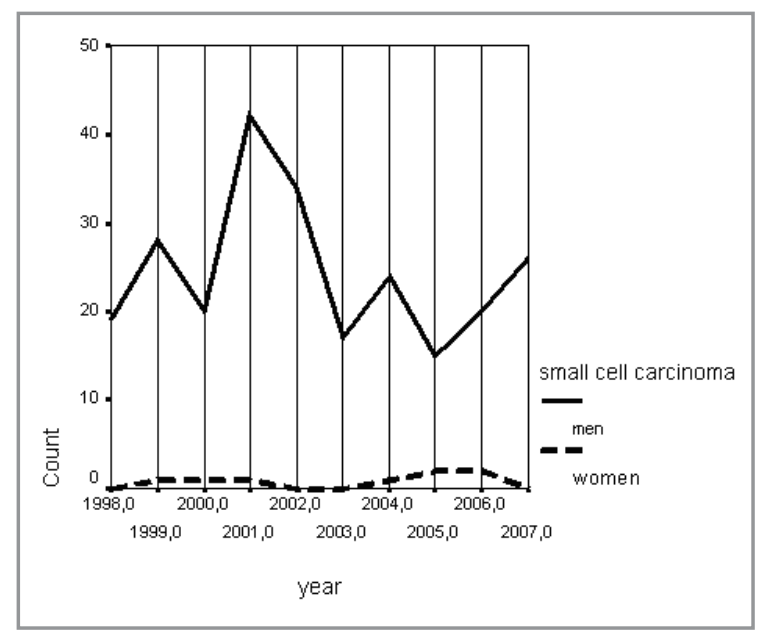

Figure 3. Graphics showing the changes of small cell lung carcinoma with gender for all patients during 1998-2007.

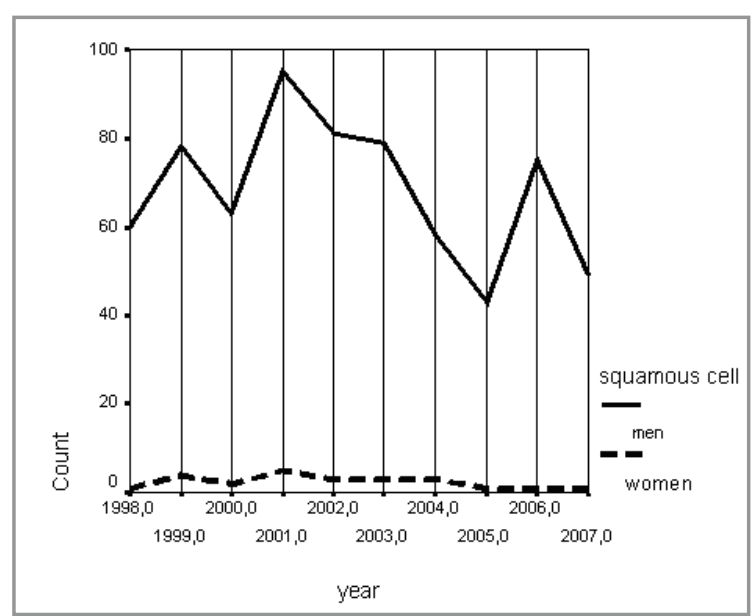

Figure 2. Graphics showing the changes of squamous cell lung carcinoma with gender for all patients during 1998-2007.

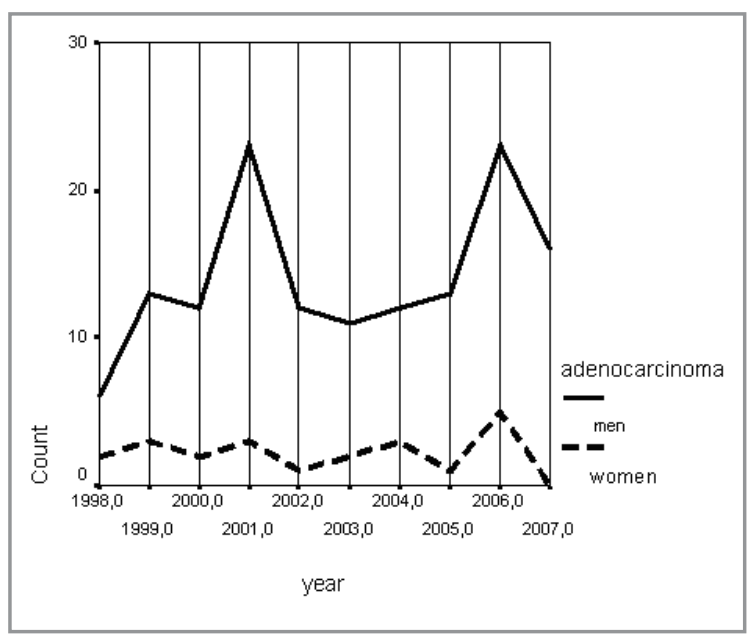

Figure 4. Graphics showing the changes of lung adenocarcinoma with gender for all patients during 1998-2007. 
te 1970s, the first evidence of a shift toward a predominance of adenocarcinoma was noted ${ }^{6.8}$ Adenocarcinoma of the lung is now the most common histological type of lung cancer. ${ }^{5.9}$ The decrease in lung cancer rates has been more rapid in squamous cell and small cell carcinomas than in adenocarcinoma, which has just recently begun to show a lower incidence rate. ${ }^{5}$

While the changing patterns of diagnosis and classification of lung cancers could have led to these changes over time, most observers have overlooked an artifactual change. ${ }^{6.8}$ Beginning in the 1970s, new techniques for the diagnosis of lung cancer became available, including the fiberoptic bronchoscope and fine-needle aspiration. ${ }^{10}$ Improved stains for detecting mucin, the hallmark of adenocarcino$\mathrm{ma}$, were also introduced in that era. Using the data from the Connecticut Tumor Registry, Thun et al. showed that the increase in the incidence of adenocarcinoma had antedated these diagnostic innovations. ${ }^{10}$

Hypotheses regarding the shift in histopathology have focused on the potential role of changes in the characteristics of cigarettes and the consequent changes in the doses of carcinogens inhaled..$^{11-14}$ The puff volume has probably increased in recent decades with the possibility of a change in the patterns of deposition in the lung, with a tendency towards enhanced deposition of tobacco smoke in the peripheral airways and the alveoli. ${ }^{14}$

There is evidence that the tar yield of cigarettes is related to the risk of developing lung cancer, since most carcinogens from tobacco smoke are present in the tar fraction. During the last 50 years, the tar yields of cigarettes have been reduced significantly. From 1950 to 1980, the tar yields of unfiltered and filtered cigarettes were reduced by $50 \%$ by modifying the type of tobacco used in the manufacture of cigarettes and by introducing filters. Filtered cigarettes first dominated the market in developed countries, such as the USA and European countries in the 1960s, and in developing nations such as Turkey in the 1980s. The levels of nitrate, which enhances the combustion of tobacco, have also increased in tobacco smoke. While more complete combustion decreases the concentrations of polycyclic aromatic hydrocarbons, the increased production of nitrogen oxides contributes to the increased forma- tion of tobacco-specific nitrosamines. An increase in the dose of the potent tobacco-specific nitrosamine NNK has been postulated as one factor leading to the increase in the incidence of adenocarcinoma. ${ }^{14,15} \mathrm{NNK}$ induces lung carcinomas in mice, predominantly adenomas and adenocarcinomas, regardless of the route of administration. ${ }^{15}$

It is well known that 20-packs-year smoking is considered heavy smoking, since the risk of lung cancer particularly increases when 20-packs-years of smoking is exceeded. Since the changes in the quality of cigarettes, tar yield, and filters occurred in the 1980s in Turkey, the estimated time for the beginning of an increase in adenocarcinoma would be the first years of the 2000s. In fact, the results of our study are consistent with this estimate and thus seem to strengthen the link between the histopathology of lung cancer and the characteristics of cigarettes smoked over time. Due to the need for longitudinal observation, only a few studies can provide data for testing these hypotheses. Thun et al. compared the risks for lung cancers of different histologic types among participants in CPS I and CPS II of the American Cancer Society. ${ }^{10}$ They found markedly increased risks for adenocarcinoma of the lung associated with smoking in both men and women over an approximate period of 20 years separating the two studies. They concluded that "the increase in lung adenocarcinoma since the 1950s is more consistent with changes in the smoking behavior and cigarette design than with diagnostic advances"). The hypothesis has been put forth that women may have a greater risk of lung cancer than men at the same level of smoking, based on possible hormone-related differences in responses to carcinogens. The evidence is limited and mixed, and the 2001 Report of the Surgeon General did not reach a conclusion on this issue. ${ }^{16}$ We do not have sufficient data on this issue, since we do not know certain figures of smoking in our population. However, we must emphasize that a large part of our patients were males with a heavy history of smoking.

In conclusion, although squamous cell carcinoma is the most common type of lung cancer, adenocarcinoma is the only type the incidence of which has been increasing strikingly, which would seem to be due to changes in the characteristics of cigarettes. 


\section{REFERENCES}

1. Parkin DM, Pisani P, Ferlay J. Global cancer statistics. CA Cancer J Clin 49: 33-64, 1999.

2. Pisani $P$, Parkin DM, Bray F, et al. Estimates of the worldwide mortality from 25 cancers in 1990. Int J Cancer 83: 18-29, 1999.

3. Bilello KS, Murin S, Matthay RA. Epidemiology, etiology, and prevention of lung cancer. Clin Chest Med 23: 1-25, 2002.

4. World Health Organization. World Health Report: 1997: Executive Summary. Geneva, World Health Organization, 1997: 1-13.

5. Wingo PA, Ries LA, Giovino GA, et al. Annual report to the nation on the status of cancer, 1973-1996, with a special section on lung cancer and tobacco smoking. J Natl Cancer Inst 91: 675-690, 1999.

6. Churg A. Lung cancer cell type and occupational exposure. In: Samet JM (ed). Epidemiology of Lung Cancer. New York, Marcel Dekker, 1994: 413-436.

7. Vincent RG, Pickren JW, Lane WW, et al. The changing histopathology of lung cancer: a review of 1682 cases. Cancer 39: 1647-1655, 1977.

8. Charloux A, Quoix E, Wolkove N, et al. The increasing incidence of lung adenocarcinoma: reality or artefact? A review of the epidemiology of lung adenocarcinoma. Int J Epidemiol 26: 14-23, 1997.

9. Travis WD, Travis LB, Devesa SS. Lung cancer. Cancer 75 (Suppl. 1): 191-202, 1995.

10. Thun MJ, Lally CA, Flannery JT, et al. Cigarette smoking and changes in the histopathology of lung cancer. J Natl Cancer Inst 89: 1580-1586, 1997.

11. Albert AJ, Samet JM. Epidemiology of lung cancer. Chest 123: 21-49, 2003.

12. National Cancer Institute (NCl). The FTC Cigarette Test Method for Determining Tar, Nicotine, and Carbon Monoxide Yields of US Cigarettes. Monograph 7. Bethesda, MD, National Institutes of Health, 1996.
13. Wynder EL, Muscat JE. The changing epidemiology of smoking and lung cancer histology. Environ Health Perspect 103 (Suppl. 8): 143-148, 1995.

14. Hoffmann D, Hoffmann I. The changing cigarette, 1950-1995. J Toxicol Environ Health 50: 307-364, 1997.

15. Hecht SS. Tobacco smoke carcinogens and lung cancer. J Natl Cancer Inst 91: 1194-1210, 1999.

16. US Department of Health and Human Services (USDHHS). Women and Smoking: A Report of the Surgeon General. Rockville, MD: US Department of Health and Human Services, 2001.

\section{Correspondence}

Dr. Şevket ÖZKAYA

Rize Üniversitesi Tıp Fakültesi

Göğüs Hastalıkları Anabilim Dalı

Rize / TURKEY

Tel: (+90.464) 6906816

e-mail: ozkayasevket@yahoo.com 